$\frac{\mathrm{DE}}{\mathrm{G}} \stackrel{\substack{\text { DE GRUYTER } \\ \text { OPEN }}}{\text { DOI 10.1515/ethemes-2014-0031 }}$

\title{
CONGRESS TOURISM AS A MARKET NICHE OF BUSINESS TOURISM
}

\author{
Vukašin Šušić \\ University of Niš, Faculty of Economics, Serbia \\ $\bowtie$ vukasin.susic@eknfak.ni.ac.sr \\ Jovica Mojić \\ 凶jmojic@sezampro.rs
}

UDC

338.48

Review paper

Received:

17.12.2014

Accepted:

29.01.2015

\begin{abstract}
Congress tourism is a highly lucrative segment of the tourist offer, which usually happens outside the tourist season. The development of congress tourism requires the existence of high-quality congress tourism offer that will meet the needs of the participants and organizers of the conference. Participants in congresses are demanding guests, but also capable of payment, but they need to ensure all necessary preconditions for quality work, but also to adequately have free time. In this regard, the fundamental role of congress tourism is to promote tourism with well-organized system of promotional activities, continuing education, personnel, market research, application of quality standards etc. Congress tourism, and all the facilities are very important in the future tourism development in Serbia, especially when it comes to large gatherings that generate significant revenue. The aim of this paper is to analyze the main characteristics of congress tourism market in the world and Serbia, which has all the requirements to become a leading destination of this form of tourism in Southeastern Europe.
\end{abstract}

Keywords: Congress tourism, tourist offer, development of tourism, destination, participants

\section{Introduction}

The process of globalization, rapid technological development, as well as more numerous networks of scientific research and educational institutions, created the need to exchange experiences in various fields of human knowledge and educate personnel from the economic and non-economic activities. Modern scientific and technological development has influenced the need for closer 
co-operation between businesses and scientists in national and international level. In order to achieve cooperation, and at the same time there was an exchange of experiences and opinions, organizes a number of different types of sets. Their program contents depend on the structure of the professional participants. The abundance of organizing these meetings and contributed to the creation of new forms of tourism - business tourism. Business tourism includes various meetings, seminars, conferences, conventions, symposiums, exhibitions, prize trips, events that contribute to connecting people and sharing of knowledge and information. This form of tourism because of the high tourist consumption and involvement of all economic and non-economic activities in the implementation of these developments, among the most profitable forms of tourism (Štetić, 2007). In the office of tourism as a separate market niche called congress tourism, in fact, congress tourism can be seen as a subset of the broader field of tourism - business tourism (Ficarelli, et al., 2013, p. 7). However, despite the daily use of the term ICCA (International Congress and Convention Association) has not proposed a single definition of congress tourism.

Visitors within congress tourism travel for specific purposes that is often related to their workplace. Although in the framework of congress tourism are in the domain of business trips are often mandatory and conditional workplace, task or project, all tourist receptive countries are very happy and these passengers fall into the group of tourists, calculating the income of congress tourism total tourist revenue. In accordance with the characteristics of participants who attend various meetings, congress tourism is considered one of profitable forms of tourist movements. Of all the groups in tourism, the participants of conferences are guests of your money and expect services with the label: accuracy, reliability, quality, comfort, speed, suitability, flexibility, originality, creativity and innovation. These are the basic principles according to which should be organized every congress.

First trip for business reasons has emerged simultaneously with the appearance of the first forms of trade (exchange of agricultural products). With the development of urban centers and large empires such as Egypt, Persia, Greece and Rome, developed and trade, and often traveled to distant lands thousands of kilometers in order to obtain different products and valuables. In the middle ages, the trading will continue, primarily due to numerous and large trade fairs that were held in cities and towns placed on the major roads. Trade show lasted for several days, which is through the services of accommodation, food and entertaining service brought significant economic benefits to the local population (Allen, et al., 2002).

In the late 19th and early 20th century in Western Europe and the USA with the help of a wide network of different associations of numerous trade associations, academic institutions, and political parties, organize large 
gatherings with hundreds, even thousands of participants. As towns soon noticed the economic benefits of organizing these meetings, they are established convention centers with the aim to present a particular city as a convention destination or a place suitable for meetings (Lucianović, 1980).

Since the 60s of the 20th century a number of factors have contributed to the increase in business travel, but also the development of tourism in general (democratization of society, the growth of personal income, the excess of free time, the development of transport, new technologies, etc.). Also, this period revealed increase in investments in the infrastructure, which is essential for the maintenance of conventions, conferences, congresses and similar meetings. The 90s of the 20th century are characterized by the highest rate of investment in the construction and renovation of congress facilities. Europe, North America, Australia and Asia are certainly the most attractive areas for investment in conference facilities. In the past 20 years, important projects were launched throughout Asia, in the former Eastern bloc countries (Hungary, Czech Republic), the Middle East and some African countries, primarily in South Africa.

Because of the high degree of tertiarization, congress tourism directly and indirectly influence the development of tertiary activities, especially in trade, catering and hotel management, service trades and transportation. It may be pointed out that the promotion of tourism certain tourist destinations, a combination of elements generated by improving, innovating and implementing changes that involve the most complex needs of tourists on the one hand and the ability to increase tourist income, reducing seasonality on the other side (Whitfield, 2007).

According to the World Tourist Organization (WTO), about 30\% of the international tourist movements belong to the so-called non-tourist developments, including the important place occupied by congress. From year to year the number of congresses, symposiums, conferences, conferences, meetings, growing in all countries. The progressive increase in the number of meetings has surprised and very bold futurologist. Today, congress tourism as one of the most important sectors of the tourist industry. Due to organizing meetings outside the main tourist season and high tourist consumption, the largest part of tourist income in the world belongs to this segment of the tourist offer (Dragićević et al. 2009, p. 129).

\section{The Concept and Importance of Congress Tourism}

Congress tourism is a specific form of tourism in which the main motivation for travel is not a holiday but an active or passive participation of individuals at conferences and events of different characters (Geić, 2011). 
Congress is set to be organized to exchange opinions and ideas, send specific messages, exchange of scientific opinions, open debate, giving publicity to a particular subject or field, etc. So congress is the kind of business events, bringing together people from different spheres of social life, to discuss on various topics of interest. These events can be commercial or non-commercial, and can last from a few hours to a week.

Under the term congress means a regular gathering of large groups of individuals to discuss a certain topic. Congress usually lasts several days, with multiple concurrent sections and is organized on a multi-annual or annual basis. Meetings of national character are often organized in relation to international and world congresses (Rogers, 2006).

Congress tourism today is a growing segment of the tourism market, because, due to globalization, the emergence of new markets in the sphere of interest of major international companies, development of technology and science, human has the need to travel, to meet other people who have the same or similar interests, listen and speak with recognized experts in their field, in order to professionally improve, exchange ideas or opinions, or present a new product (service) (Dragićević 2008).

Congress tourism is a combination of travel, accommodation and most importantly of all, organizational services intended for business tourists, who are known as the most demanding market segment. Congressional activity is specific and requires as well as the entire tourism, lots of living labor, and personal responsibility. However, congress activity that is much broader than the classical tourism covers a much wider area. Although meetings (meetings) or conferences last only a few days, preparations last (especially for large international meetings) for several years. Every encounter is unique, specific and unrepeatable. The participants of the meeting and their guests at the congress place spend 5-6 times more than the average tourist. The causes for such increased purchasing power in the structure of these guests. Congressional activity is the exclusive type of tourism, but also demands greater than the "classic" tourism, among other things, the greater part of the costs covered by the institutions that individual or group indicate congress.

The most important features of congress tourism are:

- It takes place throughout the year, providing permanent employment to full-time work;

- Refines the tourism sector relying on external infrastructure and bringing jobs to destinations like attractive areas that would otherwise have to rely on the relatively short summer season;

- Investments in congress tourism lead to the development of the tourist towns in the interior; 
- From investment destinations in the needs of business tourists (hotels, restaurants, transport and communications) realized the benefits of which can benefit the tourists who come to the classic holiday, but locals;

- Congress tourism stimulates future new business investment because people can identify their interest in the valuation of the attractions in the area;

- Congress tourism offers more value with fewer negative consequences for the environment by mass tourism;

- Congress participants usually come in groups and need to be informed and familiar with the place they come to make their stay more pleasant and efficient (Geić, 2011).

Congress has a very important social role because participants meet friends, colleagues or people with whom could share their knowledge and experience. Congress in its composition except for educational and social sides includes recreation with numerous natural and cultural attractions during congresses, before or after.

The recreational side refers to the common practice of the participants to come earlier or stay longer, and thus prolongs their stay and also achieves additional spending. Some institutions deliberately organized congresses in attractive locations in order to motivate their employees, and thus they offer a variety of interesting recreational activities under the program, so it does not look like a typical congress but as incentive travel or prize trip for a job well done.

In terms of congress tourism the most common forms of organizing congresses, conferences, seminars, symposia and scientific and professional meetings. They have their specificities within their tourist supply and demand. Much of the conference is held outside the main tourist season, and therefore the greater the possibility of extending the stay of participants of meetings and their escorts, offering a variety of tourist programs. Also, advance science and technology closer to people of different nationalities and cultures, certain scientific and professional commitments. In addition, conferences are important from the point of view of national propaganda and tourist values of the host country, peace in the world and the like. (Štetić, 2006).

Meetings are considered the foundation of urban tourism. The important thing about the conference and its participants is that the participants of the congress during the congress have greater power than the average tourists who visit the same place, but with a different motive arrival. Another important feature of congress tourism is that it is not determined by the time, i.e. congress season lasts the entire year regardless of the season.

Congress tourism is a form of economic sectors defined by the concentration of people in time and space surrounded specialized knowledge or topics that require multidisciplinary meetings. 
Transmission, exchange and renewal of knowledge, constitutes the main objects of activities and socio-cultural and economic consequences of these activities are enormous. According to its characteristics, there are other conferences or professional meetings, focused on leisure and unscientific topics, based on the exchange of experiences and ways of life. In accordance with the report of the international association of congress tourism ICCA (International Congress and Convention Association), congress tourism in the world today covers almost a quarter of the total international tourism arrivals and foreign exchange inflows.

Scheme 1. Classification of expert scientific events

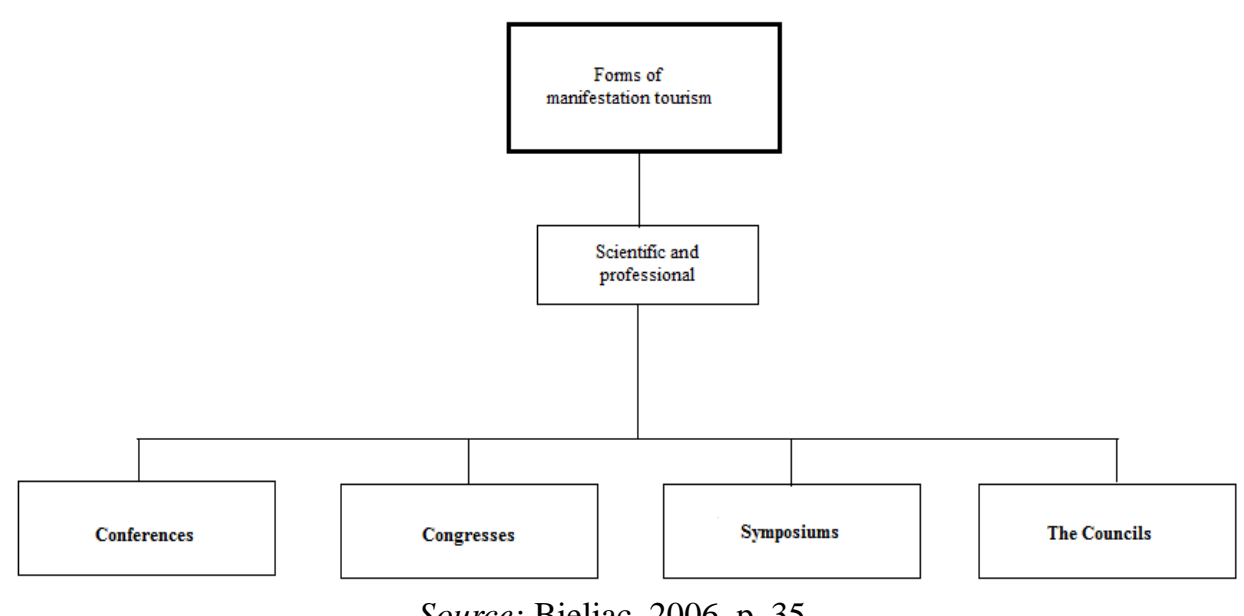

Source: Bjeljac, 2006, p. 35

We can distinguish between different types of gatherings and events that we call congress events in a broader sense, the most important are the following (Dulčić, 2005):

- Congress events that include various types of assembly depending on the objectives, the exchange of ideas and experiences, problems for which they are maintained. According to the topics discussed may differ manifestations of the economic, political, social, scientific contents, etc.

- Meetings political, religious, sports and big events internationally important cultural and artistic content (art exhibitions, concerts), religious or sporting facilities (Olympic games, world championships in a particular discipline) or content associated with the world of the spectacle (film, music, festivals).

- Fair events bring together participants who are exposed to limited space they offer and those who are interested to learn from this offer. Fairs are a very important instrument of communication of various institutions and companies from the market. Participants at the fair exhibit their achievements, different goals, compare with the competition, establish relationships with suppliers. 
Here visitors can assess the complexity of the offer certain market and look for information about available spare products.

Given the similar infrastructure needs congresses and fairs all the common trend of building multifunctional congress centers that can be done within its premises to be adapted to the needs of fairs and congresses. At the same time, trade fairs expanded its range by adding congress halls with necessary equipment. Facilities required in a material part of congress tourism are: conference rooms, exhibition space and multifunctional hall. Then translation equipment and modern audiovisual, computer and video equipment (sound system, projectors, etc.), As well as high-quality hotel accommodation and staff, protocol official and leisure activities (excursions and tours), food and beverages adapted the international structure of participants and others. (Ficarelli et al., 2013, p. 8).

In addition to the positive, congress tourism can have negative social and environmental impact in the area. Congress participants usually move in mass in a short period of time, which can lead to traffic congestion, increasing congestion in parking places, restaurants, shops and others. This is especially true in destinations that have lower spatial coverage (mountainous, coastal destinations, etc.) When the number of participants cannot exceed the carrying capacity of the destination (Whitfield, 2007).

\section{Congress Tourism Destinations in the World}

ICCA (International Congress and Convention Association), the leading international association meetings industry publishes the annual number of international conferences held in the Association. Only those international association meetings that meet three criteria maintained continuously, rotate between at least three countries and have at least 50 participants (http://www.poslovniturizam.com).

Congress tourism demands and quality characteristics of destinations, regions and countries in which it maintains, such as political and social security, cultural and historical monuments, adequate hotel infrastructure, natural attractiveness, cuisine, the possibility of organizing memorable and original events and the like. "The participants are usually highly educated, skilled and reputable persons whose ratings are very important, but they also represent the individual media advertising" (Štetić, 2006, p. 23).

The most attractive destinations are the urban centers, coastal resorts, which offer adequate space, facilities, quality accommodation facilities, high level of safety and efficient traffic. Decisive for the extension of the stay of the guests play the attractiveness of the destination. 
Table 1 Number of meetings held by the countries in the world

\begin{tabular}{||c|c|c|c|c|c|c|c||}
\hline & The leading countries & $\mathbf{2 0 0 3}$ & $\mathbf{2 0 0 5}$ & $\mathbf{2 0 0 7}$ & $\mathbf{2 0 0 9}$ & $\mathbf{2 0 1 1}$ & $\mathbf{2 0 1 2}$ \\
\hline 1 & U.S.A. & 625 & 728 & 768 & 875 & 877 & 833 \\
\hline 2 & Germany & 363 & 454 & 573 & 615 & 626 & 649 \\
\hline 3 & Spain & 312 & 361 & 403 & 448 & 496 & 550 \\
\hline 4 & United Kingdom & 336 & 420 & 423 & 437 & 487 & 477 \\
\hline 5 & France & 309 & 375 & 406 & 441 & 476 & 469 \\
\hline 6 & Italy & 329 & 340 & 409 & 480 & 428 & 390 \\
\hline 7 & Brazil & 137 & 201 & 227 & 310 & 305 & 360 \\
\hline 8 & Japan & 210 & 262 & 315 & 320 & 244 & 341 \\
\hline 9 & Netherlands & 194 & 239 & 247 & 307 & 322 & 315 \\
\hline 10 & China & 89 & 239 & 306 & 340 & 343 & 311 \\
\hline 11 & Austria & 152 & 199 & 253 & 267 & 286 & 278 \\
\hline 12 & Canada & 173 & 217 & 263 & 261 & 268 & 273 \\
\hline 13 & Australia & 175 & 193 & 225 & 207 & 209 & 253 \\
\hline 14 & Switzerland & 171 & 204 & 204 & 242 & 259 & 241 \\
\hline 15 & Sweden & 147 & 165 & 174 & 235 & 208 & 233 \\
\hline & & & & & & & \\
\hline $\mathbf{4 6}$ & Serbia & $\mathbf{4}$ & $\mathbf{1 2}$ & $\mathbf{1 9}$ & $\mathbf{3 7}$ & $\mathbf{5 8}$ & $\mathbf{5 2}$ \\
\hline
\end{tabular}

Source: International Congress and Convention Association, 2013,

ICCA Statistics Report, The Association Meetings Market 2013.

World congress industry each year achieves revenue of 11 billion dollars and currently the leading center of congress tourism in the world is Paris, which last year organized 204 international congresses. It is followed by Madrid with about 186 deals with 182, while Belgrade last year's 52 international congresses. According to the International Congress and Convention Association ICCA (International Congress and Convention Association), 57 percent of congress events happening in Europe, 21 percent in Asia, the Pacific and Australia, while 11 per cent is held in the United States and Canada. The average duration of the congress was 3.9 days and the average consumption per delegate is about $\$ 2,000$, while the average fee 526 dollars. Delegates are less retained than five years ago, when measured over an average stay of four days, but the increased number of participants congresses.

In recent years, Serbia has returned to the international MICE market, emphasizing its dynamic development, so in 2013 the ICCA list ranked 42nd in the world in the number of events held. Like other countries in the region, Serbia takes full advantage of interest in Southeastern Europe.

Serbia is a key her position, given that there is at the crossroads, and the fact that Belgrade is the largest city and also the center of business, cultural and 
social activities. New investments in Serbia led to the opening of the new airport terminal, conference facilities, hotels and roads, resulting in significant capacities of higher category. Improving transport links, good hotels, and high-quality services that Serbia is one of the most appealing destinations for congress tourism in this part of Europe. From the metropolis of Southeastern Europe increasing number of congresses organized by only deals. Daily average per participant in Belgrade is 450 euros, and guests are most likely to stay for three days. Meetings have from 500 to 3,000 participants.

Serbia has progressed from 72 to 42 place in 2013 in the list of congress destinations, and Belgrade took fourth place in the Eastern Europe, the results of the International Congress and Convention Association ICCA (International Congress and Convention Association).

With 66 international conferences held in 2013, which meet strict criteria ICCA, Serbia has achieved the best result so far. In 2007, when the Serbian Convention Bureau was established as part of the TOS, Serbia was on the 72nd position with only 11 sets, as in the previous period, the fastest growing congress destination in Europe. With this result Serbia's fifth destination in Eastern Europe. The largest part of the business convention takes place in Belgrade, with 52 internationally recognized set of shared 44th place with Melbourne, but in par with cities such as Washington, Athens, Montevideo, Florence. Among direct competitors from Eastern Europe is in 4th place, behind Prague, Budapest and Warsaw, and in front of Moscow, Bucharest, Krakow, St. Petersburg, Zagreb, Ljubljana.

Belgrade and Serbia at the beginning of 2013 reached the list of top 50 congress destinations in the world. Congress development of tourism is very important for every country, and employed in the tourism industry know best how the congress guest desirable. He is staying in a hotel, it pays the fee for participation in the Congress, and the path starts with a daily allowance as a rule, to spend the last penny.

The attack on the world market Conference, Belgrade until a few years ago had an insufficient number of hotels, especially those of higher category. This problem is resolved. Belgrade today has 8,500 beds in 67 hotels. The four hotels are five-star, four-star 29 hotels, three star hotel has 21, 11 two-star and two hotels - one star. 
Table 2 ICCA ranking list of the leading countries, according to the number of meetings held in 2013

\begin{tabular}{|c|c|c|}
\hline & The leading countries & Number of meetings \\
\hline 1 & USA & 829 \\
\hline 2 & Germany & 722 \\
\hline 3 & Spain & 562 \\
\hline 4 & France & 527 \\
\hline 5 & United Kingdom & 525 \\
\hline 6 & Italia & 447 \\
\hline 7 & Japan & 342 \\
\hline 8 & China & 340 \\
\hline 9 & Brazil & 315 \\
\hline 10 & Netherlands & 302 \\
\hline 11 & Canada & 290 \\
\hline 12 & The Republic of Korea & 260 \\
\hline 13 & Portugalia & 249 \\
\hline 14 & Austria & 244 \\
\hline 15 & Sweden & 238 \\
\hline 16 & Australia & 231 \\
\hline 17 & Argentina & 223 \\
\hline 18 & Turkey & 221 \\
\hline 19 & Belgium & 214 \\
\hline 20 & Switzerland & 205 \\
\hline 21 & Singapur & 175 \\
\hline 22 & Finland & 171 \\
\hline 23 & Poland & 170 \\
\hline 24 & Denmark & 161 \\
\hline 25 & Mexico & 158 \\
\hline 26 & Czech Republic & 145 \\
\hline 27 & India & 142 \\
\hline 28 & Columbija & 139 \\
\hline 29 & Ireland & 136 \\
\hline 30 & Norway & 136 \\
\hline 40 & Russia & 83 \\
\hline 41 & Croatia & 69 \\
\hline 42 & Serbia & 66 \\
\hline
\end{tabular}

Source: International Congress and Convention Association, International Association of modern history, 2013. 
Table 3 ICCA ranking list of the leading cities in terms of the number of meetings held in 2013

\begin{tabular}{|c|c|c|}
\hline & The leading cities & Number of meetings \\
\hline 1 & Paris & 204 \\
\hline 2 & Madrid & 186 \\
\hline 3 & Vienna & 182 \\
\hline 4 & Barcelona & 179 \\
\hline 5 & Berlin & 178 \\
\hline 6 & Singapur & 175 \\
\hline 7 & London & 166 \\
\hline 8 & Istanbul & 146 \\
\hline 9 & Lisbon & 125 \\
\hline 10 & Seul & 125 \\
\hline 11 & Prag & 121 \\
\hline 12 & Amsterdam & 120 \\
\hline 13 & Dablin & 114 \\
\hline 14 & Buenos Aires & 113 \\
\hline 15 & Brisel & 111 \\
\hline 16 & Kopenhagen & 109 \\
\hline 17 & Budapest & 106 \\
\hline 18 & Beijing & 105 \\
\hline 19 & Roma & 99 \\
\hline 20 & Bangkok & 93 \\
\hline 21 & Stockholm & 93 \\
\hline$\overline{22}$ & Sydney & 93 \\
\hline 23 & Hong Kong & 89 \\
\hline 24 & Helsinki & 85 \\
\hline 25 & Munich & 82 \\
\hline 26 & Rio de Janeiro & 79 \\
\hline 27 & Tokio & 79 \\
\hline 28 & Taipei & 78 \\
\hline 29 & Shanghai & 72 \\
\hline 30 & Montreal & 71 \\
\hline 44 & Belgrade & 52 \\
\hline$\overline{45}$ & Melbourne & 52 \\
\hline 46 & Porto & 51 \\
\hline
\end{tabular}

Source: International Congress and Convention Association, International Association of modern history, 2013. 


\section{Congress Capacity of Serbia}

Conference Tourism in Serbia since 2000 recorded accelerated growth. Unfortunately, profit could be much greater by building new convention facilities.

It is important to have a modern and a convention center, but not crucial. Many conferences to gather 1,300 participants, and such sale are some of our hotels. The advantage of Serbia is easy access to the air carrier "Air Serbia", which has a daily lines to all major cities.

The top ranking convention destination for organizing international conferences in our country as Belgrade and Novi Sad, as they have the largest conference facilities and easiest transfer. Congress tourism is an important segment of the tourist offer of Belgrade, because the city has all the necessary resources for this type of tourism: smešajni facilities, conference halls, exhibition halls, accompanying tourist programs and experienced conference organizers. In positioning Belgrade as a congress destination in order to the Belgrade Convention Bureau, which is an organizational unit within the Tourist Organization of Belgrade. The main task of the Convention Bureau is to promote Belgrade as a congress destination and a number of its activities significantly influence the successful development of the meetings industry. Seminars, symposia, congresses, fairs and scientific and professional meetings are organized throughout the year in the number of convention and trade fair buildings in Belgrade, among which the most important are Sava Center, Belgrade Fair, Belgrade Arena and Expo XXI. In addition, a greater number of hotels in Belgrade have significant capacity congress (www.tob.co.yu).

Sava Center is the largest congressional, cultural and business center in Serbia and one of the largest in Europe, whose main role is to organize congresses and art conventions and events. In the vicinity there are hotels of the highest category of Hyatt Regency, Falkensteiner Hotel Belgrade and Crowne Plaza (formerly "Belgrade continental"). "Sava Center" has 15 halls equipped with the latest audio equipment and multi-channel simultaneous interpretation system (Infra Red), a system for multimedia presentations, Internet connection, as well as superb a lighting technique.

Sava Center is the largest congressional, cultural and business center in Serbia and one of the largest in Europe, whose main role is to organize congresses and art conventions and events. In the vicinity there are hotels of the highest category of Hyatt Regency Belgrade Falcestaeiner Hotel and Crowne Plaza (formerly "Belgrade continental"). "Sava Center" has 15 halls equipped with the latest audio equipment and multi-channel simultaneous interpretation system (Infra Red), a system for multimedia presentations, Internet connection, as well as a superb lighting technique. 
"Sava Center" is a modern center of national and international repute who has three decades of experience in organizing major international congresses and art events. It has hosted more than 7,000 domestic and international meetings and events with more than 1.5 million participants and 8,000 cultural events attended by more than 7,000,000 visitors. Sava Center is a member of a number of international congresses and art associations such as ICCA, International Association convention centers and the International Society of Performing Arts (International Society of the Performing Arts - ISPP) (www.savacentar.com). Despite the significant capacity of 7,000 seats it is necessary to modernize the convention center or the construction of a convention center custom demands of sponsors and participants of the congress.

Novi Sad, as well as administrative, economic, cultural, scientific and educational center of Vojvodina, is a destination suitable for organizing different character sets. The city organizes trade fairs for decades and, therefore, merits the epithet "fair" city. With fairs or exhibitions intended for the general public, organized and professional meetings, seminars, presentations, workshops, lectures, conferences, with the aim of bringing together experts in the particular field, exchange knowledge, ideas and opinions. The opening of the congress, exhibition and business-shopping center "Master" at the Novi Sad fair 2006 are enlarged convention facilities in Novi Sad. The new facility with $28,000 \mathrm{~m}^{2}$ multi-purpose space provides superior service to business people who demand that the one place to get a whole range of highly professional services at the level of the European convention centers. The congress complex with 1,200 seats, but the system of movable walls this space if necessary, can turn into seven smaller conference rooms (www.sajam.net).

Apart from Belgrade and Novi Sad, Serbia Convention Bureau promotes and Subotica with sticks, Kopaonik, Zlatibor, Vrnjci Spa, Vršac and Niš as an important destination for organizing congresses and other meetings, primarily national and regional character.

Zlatibor is one of the leading mountain resorts in Serbia. There are facilities for relaxation and recreation throughout the year, and it also successfully organized national and regional conferences. Hotel "Palisad" with 450 rooms is the largest in the city and was renovated in August 2005. Centre "Serbia", the city conference center with 600 seats, a former hospital, reconstructed for the purpose of organizing meetings in 1984. Most meetings of the national character are held there. Medical Center "Čigota", with 180 rooms and conference hall of 350 seats, a host of national and regional conferences in the field of medicine.

Besides Zlatibor, Kopaonik, and has favorable conditions for congress tourism throughout the year. The apartment complex Konaci "Sunny Peaks" placed a special multi-purpose conference center. The tower Konak is a large 
congress hall with 450 seats and several smaller hall (TV room - 60 seats, Yugotours Holliday Club - 160 seats, President hall - 30 seats) is primarily intended and modernly equipped for organizing congresses, symposia and seminars.

Vrnjci Spa, a leading spa resort in Serbia, annually visited by about 100,000 people, of which 15,000 of the participants were 350 conferences. The unique features of the city and proximity to the historic and architecturally significant monastery makes this an attractive center for organizing meetings of national and regional importance. The largest center for the plenary meeting in Spa has 1,200 seats and $760 \mathrm{~m}^{2}$ of exhibition space. Vrnjci Spa has 24 hotels with approximately 3,000 rooms.

Vršac is the seat of the largest pharmaceutical company "Hemofarm" in Serbia, which could be a logical connection to attract companies in the region to organize meetings in the field of medicine in this city. The city has a modern sport-business center "Millennium" with 3,600 seats, designed to the highest standards. Thanks to the magnificent hall of the Centre, the city of Vrsac has become one of the hosts of the European Basketball Championship in 2005 on an area of 11,800 $\mathrm{m}^{2}$ (www.vrsac.com).

Subotica with sticks, thanks to a favorable traffic-geographical position, near the border with Hungary, as well as its rich cultural heritage and protected natural resources in the area, a destination to which annually holds around 200 national and regional conferences. In the center of Subotica in 2007 he opened the hotel-conference and business center "Galleria" with four stars, which are magnified and accommodation and convention facilities in town. This building area of $29,000 \mathrm{~m}^{2}$ consists of three units: a hotel, a business center and a shopping mall that connects the covered atrium. The hotel also has seven fully equipped, air-conditioned hall intended for seminars, conferences and congresses. Hotel "Patria" (4*) in Subotica has a conference hall with 250 seats. The congress capacity Palic are: Eco-Center with 120 seats and the necessary equipment for organizing conferences, large terrace with 600 seats, which is being renovated, and the restaurant "Small tavern" (4*), which is composed of congressional service. This restaurant has two "Park" and "Jezero" (4*), capacity of 118 beds. In the immediate vicinity is located the hotel "President", with 80 beds and a conference room, where it is possible to organize small meetings up to 50 participants.

Congress tourism in Niš, unfortunately, the closure of the hotel "Serbian tourists" like "Nais", "Ambassador", "Park", "Partizan" and "Ozren" significantly reduce the possibilities for organizing such forms of tourism. Meetings are held in the infirmary Niška Banja "Radon", while organizing accommodation in hotels in Nis. The most common medical conferences and is held in "Radon" in Niska Banja, for example. Traditional Cardiology Congress 
in November. As organizers of smaller meetings and conferences there are also hotels such as "Tami Rezidens", "Niški cvet", "My Place", "Grand Niš" and others. Very often, the organizers of conferences such as faculties at the University of Nis, are offerd much larger rooms for conference participants. However, the problem is the accommodation of guests in the small capacity of the hotel. This reduces the possibility of communication between the parties, outside the session hall. The construction of a multifunctional congress center with several halls of different sizes would greatly complement the congress offer niche.

Previous analysis shows that the most important destination for congress tourism in the Republic of Serbia, Belgrade and Novi Sad. These cities should, through organizing major international conferences and events, what better present the tourist attractions, conference facilities and potentials of Serbia as a whole. International conferences are an opportunity not only to promote Serbia as a tourist destination and repair its image, but also a chance for the entire Serbian economy.

Promoting conventions in Serbia, advertising in leading international journals in the field of congress tourism, then presenting with world famous internet educational systems, and participation in specialized fairs congress tourism (IMEX and EIBTM) are the primary tasks of the Congress Bureau of Serbia, with the aim of attracting major international conferences in country. It is expected that in the future Beograd, Novi Sad and Niš be leading congress destination in Serbia. They are presented in the framework of the Organization of European cities (European Cities Tourism - EST) as a new attractive destinations, which are yet to be revealed, as with competitive prices, a great advantage Serbia.

\section{Conclusion}

By organizing international conferences, meetings and the like high economic effects are achieved and attract influential visitors. Conferences affect tourism development, increasing off-season traffic and create a new image of the destination. This type of tourism represents additional business in relation to recreational tourism. Conferences promote professional development through regional and international experience accessible to local communities. On the other hand, there are costs incurred by the organizer as well as organization expenses, food, refreshments, entertainment and other components of the entire congress event. However, the economic benefits related to congresses and conventions exceed the costs of individual participants, because the average daily consumption of congress guests exceeds two to three times the energy of ordinary tourists. 
Congress tourism, the Tourism Development Strategy of the Republic of Serbia (2005), put on the list of priorities, and Belgrade, Novi Sad and Niš stand out as the primary destinations where you should develop this form of tourist traffic. Bearing in mind that the global scale congress tourism is characterized by a large volume of demand, which is constantly growing, it is great average consumption per day, and that through congress tourism promote tourist destinations values, it is clear that this type of tourism can contribute to the overall tourism and economic development of Serbia. To be an attractive destination for organizers and planners of international conventions, it is necessary to dispose with quality and modern-equipped conference center, hotel capacities of the highest category, which will be aligned with the maximum convention facilities. International conferences require a good connection destination by air transport to destinations from which the largest number of participants of the congress, is expected to be a high quality transport system in the destination. Service quality, attractiveness of the destination, as well as its competitiveness in relation to the environment are factors that also influence the final decision of the organizers to choosing the destination for congresses.

The important point for the planning of adequate infrastructure is the size of congress Congress. According to available data, the majority of Congress is smaller in character and it is therefore necessary to determine the viability of building large-capacity due to the small percentage of maintaining such large conferences. International congresses can be organized by state institutions, associations or corporations. Serbia should be mainly to attract congresses associations, since they have more participants and good profits. However, every congress prestige, great promotion for the city and state, among other things, because every tenth participant returned with his family as a tourist.

Serbia has the potential to seek out new destinations, multiculturalism, something that people have not seen or experienced. This can provide in Serbia only need to complete mosaic which will include the natural beauty, cultural heritage, creative ideas and professional attitude towards guests and professional service. In order to improve the congress tourism, it is necessary to build a new conference center, renovate existing facilities in hotels and rehabilitation centers, then, build hotels with world famous brand hotel chains and thereby attract new investors.

There is a real possibility that Serbia can be a recognized congress destination, bearing in mind the congress conference facilities of the country. Another advantage is the fact that Serbia, in a way, is a new destination. In addition, the domestic scientific and professional associations are well positioned in the European and international scientific networks as well as people who are at professional meetings and conferences in the world. 


\section{References}

Allen J., W. O’Toole, McDonnell, I. and R. Harris, (2002) Festival and Special Event Management, 2nd edition. Australia: Willey Tourism Series

Bjeljac, Ž. (2006) Teorijsko-metodološke osnove manifestacionog turizma, posebno izdanje knj. 65, Beograd: Geografski institut „J. Cvijić“, SANU..

Dragićević, V. (2008) Stanje i perspektive kongresnog turizma u Novom Sadu, Novi Sad: Departman za geografiju, turizam i hotelijerstvo, PMF Univerzitet u Novom Sadu,

Dragićević, V., S. Štetić, Plavša, J., and U. Stankov (2009) Tržište kongresnog turizma-Studija slučaja: Novi Sad, Zbornik radova departmana za geografiju, turizam i hotelijerstvo, 38/2009 . 128-139.

Dulčić, A. (2005) Poslovanje turističkih agencija, Split: Ekokon.

Fenich, G., G. (2012) Meetings, Expositions, Events and Convenctions, An introduction to the Industry; third edition.

Ficarelli, S., S. Sendra, Parra, L. and J. Lloret, J (2013) Congress and Meetings Tourism and Destination Brand, The Fifth International Conference on Creative Content Technologies, 1-14,

Geić, S. (2011) Menadžment selektivnih oblika turizma, Split: Sveučilište u Splitu.

International Congress and Convention Association - ICCA Statistics Report3, Abstract for non-members, The International Association Meetings Market (2000-2010),

International Congress and Convention Association - ICCA Statistics Report 2013, Abstract for non-members, The International Association Meetings Market (2013)

Lucianović, L. (1980) Kongresni turizam, Sarajevo: Svjetlost,

Ministarstvo trgovine turizma i usluga Republike Srbije: (2005) Strategija razvoja turizma Srbija, Horwath Consulting Zagreb - Ekonomski fakultet Beograd.

Rogers, T. (2006) Conferences and Conventions: A Global Industry, Butterworth Heinemann.

Štetić, S. (2007) Posebni oblici turizma, Beograd: Forma B.

Whitfield, J., E. (2007) Why build purpose-built conference venues? Forecasting new build Journal of Retail and Leisure Property 6, 47-60. doi:10.1057/palgrave.rlp.5100045.

www.tob.co.yu

www.savacentar.com

www.sajam.net

www.vrsac.com 


\section{KONGRESNI TURIZAM \\ KAO TRŽIŠNA NIŠA POSLOVNOG TURIZMA}

Apstrakt: Kongresni turizam je izrazito unosan segment turističke ponude koji se najćešće događa van turističke sezone. Razvoj kongresnog turizma zahteva postojanje kvalitetne kongresno-turističke ponude, koja će zadovoljiti potrebe i učesnika i organizatora skupova. Učesnici na kongresima su zahtevniji gosti, ali i platežno sposobniji, pa im je neophodno osigurati sve potrebne preduslove za kvalitetan rad, ali i za adekvatno popunjavanje slobodnog vremena. U tom pravcu, osnovna uloga kongresnog turizma je da promoviše turizam uz dobro organizovan sistem promotivnih aktivnosti, kontinuiranu edukaciju kadrova, istraživanje tržišta, primenu standarda kvaliteta itd. Kongresni turizam, i svi sadržaji su vrlo važni u budućem turističkom razvoju Srbije, posebno kada je reč o velikim skupovima који generiše značajne prihode. Cilj ovog rada je da se analiziraju osnovne karakteristike tržišta kongresnog turizma u svetu i Srbiji, koja ima sve uslove da postane vodeća destinacija ovog oblika turizma u Jugoistočnoj Evropi.

Ključne reči: Kongresni turizam, turistička ponuda, razvoj turizma, destinacija, učesnici. 